ISSN: 2362-1303 (Paper) | eISSN: 2362-1311(Online)

\title{
A Critical Study of Class Ten Our English Book
}

\author{
R. K. P. Shrestha ${ }^{1} \&$ Prof. Dr. Ramnath Khanal ${ }^{2}$ \\ ${ }^{1}$ PhD Scholar, Mewar University, Chitorgarh, Rajasthan, India. \\ ${ }^{2}$ Professor of English, Tribhuvan University, Kathmandu, Nepal \\ Corresponding Author \\ R.K. P.Shrestha \\ ram_sth2010@yahoo.com
}

\begin{abstract}
A textbook holds an important place in ELT programme, particularly in an EFL setting where most teachers depend totally on the approved books, and don't bother to prepare tailor-made teaching materials. Objectives: The main objective is to critically examine the current English textbook for class ten used by all the government as well as English-medium private schools across Nepal. Methodology: A descriptive qualitative research design was adopted to evaluate the quality of the book on mainly two criteria: what to teach and how to teach, At the same time, many other things have been taken into consideration, for example, what is the quality of the input in the book from the viewpoints of four elements of language and four macro skills as well as their constituent micro skills, what is the learning outcome of the book, and so on. Result: There seems to be serious loopholes in the organization of the presentation and practice materials of the book from both viewpoints: knowledge transmission and communicative ability development. Conclusion: The book needs to be adapted and rewritten.
\end{abstract}

\section{INTRODUCTION}

This article aims at examining the contents of Class Ten Our English Book from the perspective of communicative language teaching principles. A textbook to a learner is like a meal to a person in one's life. Our meal must contain a balanced diet for the proper growth of our body and for keeping a good physical health. If the diet is deficient in the ingredients like vitamins, protein, minerals, etc, the body will not get necessary nutrition. Consequently, one will have a slow physical growth, resulting in a weak physical stature, and at the same time one may fall prey to different diseases.

Similarly, if learners are not given the right language input, their output will naturally suffer from different types of irregularities and errors like grammatical errors, lexical errors, sociolinguistic errors, strategic errors, discourse errors, stylistic errors, phonological errors, and so on. 
ISSN: 2362-1303 (Paper) | eISSN: 2362-1311(Online)

JOURNAL OF ADVANCED ACADEMIC RESEARCH (JAAR) July 2015

This is a simple analogy between language input and a person's diet. Actually, the case of language input and language learning/acquisition is much more complex and multifaceted. Furthermore, instructed language learning is more complex than naturalistic language acquisition from a number of viewpoints.

Primarily, in classroom language teaching/learning, there are two most important criteria to evaluate the English language teaching/learning contents. They are: what to teach and how to teach.

\section{What to teach?}

The four language elements: vocabulary, grammar, function and phonology

The four language skills : listening, speaking, reading and writing

The four elements of communicative competence: linguistic competence, sociolinguistic competence, discourse competence and strategic competence

The three basic practice activities: accuracy-oriented pre-communicative activities, fluency-oriented free communicative activities, confidence-building activities

\section{How to teach?}

How to teach is primarily concerned with the teacher who teaches the book employing appropriate methods and techniques. However, the textbook must provide some model teaching techniques through its exercises in consistent with current research-based pedagogical theories.

Now, let's evaluate the Class Ten Our English Book published by JEMC, Ministry of Nepal.

\section{METHODOLOGY}

A descriptive qualitative research design was adopted to evaluate the quality of the Our English Book : class ten. A reflective method was used to examine the constituents of the book, particularly, on the four criteria of the aspects of language, and the four components of communicative competence which is the ultimate goal of English teaching/learning programme.

At the same time, many other things have been taken into consideration, for example, what is the quality of the input in the book from the viewpoints of four elements of language and four macro skills as well as their constituent micro skills, what is the learning outcome of the book, and so on. 
ISSN: 2362-1303 (Paper) | eISSN: 2362-1311(Online)

JOURNAL OF ADVANCED ACADEMIC RESEARCH (JAAR)

July 2015

\section{RESULTS AND DISCUSSIONS}

The criterion of vocabulary development in the textbook

Each lesson begins with a reading passage. After the presentation of the reading text, there is just one vocabulary related exercise in each lesson, which aims at recalling some six words from the text. Obviously, that is just a skill testing exercise, not a skill building exercise.

Well, it is up to the teacher to teach the meaning and use of the words effectively in whileteaching phase, and it might be supposed for the time being that the teachers are competent enough (?) to teach each vocabulary item in the most effective way using eclectic techniques. Now comes the question of evaluation. Isn't it an effort-saving task just to test the passive knowledge of words, and not to test whether the students can use the targeted words /expressions in context? In every lesson, there is "Section 2: Ways with words" ? In this section, the passive knowledge of the vocabulary items is sought through (a) finding opposite words from the passage - Lesson 1,11 (b) puzzles - 2,4,13, (c) matching the words with their meanings $-3,5,12,14$, (c) matching words with pictures $-6,14$ (d) locating the words in the passage with the same meaning $-7,10$ (e) finding and using medicine-cum health related words from the passage -8 (f) supplying English equivalent words for the Nepali words used in the passage -9 (h) five prefixes -15 .

The importance of a good vocabulary base is beyond any dispute. Michal Swan holds that what the students need most is vocabulary (Swan, 1985).

Let's come back to Unit 1: Section 2: Ways with words in order to see what the exercise is like.

The exercise goes like this:

Find the words in the story that have the opposite meaning to those below:

Dawn (4) took off (10) huge (37)

Descended (43) primitive (37) dark (40)

Well, the numbers in brackets suggest the line in which these words occur.

The students have to find out the opposite words: twilight, landed, tiny, ascended, advanced and lit up, which almost all students in the class can either guess or copy from others successfully.

Now the million dollar question is: does this exercise guarantee that the students have grasped the central meaning of these words and can they can retrieve and use these words in 
ISSN: 2362-1303 (Paper) | eISSN: 2362-1311(Online)

JOURNAL OF ADVANCED ACADEMIC RESEARCH (JAAR)

July 2015

spontaneous speech and writing? What is the guarantee that the teacher will teach the meaning, use and pronunciation of all of these words correctly in course of explanation? What is the guarantee that the teacher knows he/she has to teach not only the meaning, but also the use of each word in appropriate sentences? Is there the guarantee that teacher gives the correct model pronunciation? What will happen if the teacher is unable to give the right concept of the meaning of these words, or if the students get the wrong concept because of the teacher's imperfect explanation? Suppose the students got the right meaning, but as the words were not presented in new contexts, the students were unable to learn their use or uses. Then what is the value of learning just the meaning of words? Suppose, the meaning and use were taught properly, but the students were not given the right model pronunciation, and consequently they happen to mispronounce the words, and in course of time such faulty pronunciations get fossilized, or in another case, suppose the students pick up faulty pronunciation from their own teacher, and they use the same faulty pronunciation while talking to native speakers. Shouldn't the textbook writer be conscious of such things while writing a language textbook? The textbook writer must anticipate such undesirable results and try to check them by appropriate exercises.

Let's think about one suggested vocabulary exercise associated with the above mentioned Section 2 Exercise. The instruction might go like this:

Replace the underlined words with the words that express the same meaning:

When we approached the city, it was getting dark as the sun had already gone down. I was about to open the gate when a huge black bird came down through the air on roof of the house next to ours. It was holding a small object in its beak. To our amazement, it dropped the object on the roof, and began climbing up the stairs using its heavy webbed feet.

T.G: The teacher has to give the right model pronunciation of targeted words and also other words.

Now let's discuss the comparative advantages of this type of exercise.

Unlike the textbook exercise, this is a skill-building vocabulary exercise, which compels learners to try to retrieve what they learnt earlier, and requires them to use the words productively. This is not just the passive recalling and guessing the meaning of words. The students will produce the same words: twilight, landed, tiny, ascending. The difference is that this time they will produce the right words not just by guessing but by understanding the meaning clearly, will use their knowledge, and will use the word 'ascending' meaningfully changing its form appropriately.

This exercise teaches learners both the meaning and use of words. 
ISSN: 2362-1303 (Paper) | eISSN: 2362-1311(Online)

JOURNAL OF ADVANCED ACADEMIC RESEARCH (JAAR)

More importantly, this type of exercise teaches some more words-in-use in discourse, typed in bold letters.

Lastly, through the instruction to the teacher, it is expected that learners will pick up correct model pronunciation of words from their teacher because teacher is supposed to consult the dictionary and give right model pronunciations to the students.

The criterion of grammar practice materials

Let's examine the grammar presentation and practice in Class ten OEB. For this purpose, we will go to Section 5: Time for grammar.

The exercise goes like this:

In expressing degrees of probability, modal (will/may/might) $+V$ is used. With 'will' the word 'probably' can also be used. Make as many sentences as possible from the following table.

\begin{tabular}{|c|c|c|}
\hline He & $\begin{array}{c}\text { (probably) } \\
\text { will/(probably) }\end{array}$ & $\begin{array}{c}\text { believe me } \\
\text { come for dinner }\end{array}$ \\
$\begin{array}{c}\text { She teacher } \\
\text { The public }\end{array}$ & $\begin{array}{c}\text { may/may not } \\
\text { might/might not }\end{array}$ & $\begin{array}{c}\text { be poor in coming years } \\
\text { get the job }\end{array}$ \\
& take the history class today \\
& raise their voice against corruption \\
\hline
\end{tabular}

Let's examine this exercise from the viewpoint of developing communicative ability as well as from the viewpoint of getting conscious grammatical knowledge.

It's crystal clear that the above exercise does not comply with communicative language teaching principles. All that the students have to do is to form sentences, which they can do just roughly using their common sense. There is no guarantee that they will differentiate between the use of 'may' and 'might', which is the specific objective of this exercise.

Suggestion: The above mentioned vague instruction could be replaced with the clear-cut rules for the use of 'may' and 'might' in a sentence or two, followed by example sentences. Then the above mentioned substitution table could be replaced by more meaningful, personalized communicative drill as follows.

Situation: One student named Ravi is absent today.

Teacher: Why is Ravi absent today? What may be the cause? Can someone guess?

Teacher directs the question to Student 1,2 and 3.

Mala: He may be ill. 
ISSN: 2362-1303 (Paper) | eISSN: 2362-1311(Online)

JOURNAL OF ADVANCED ACADEMIC RESEARCH (JAAR)

Student 2 : I don't think so. He might be busy today.

Student 3: I think he might not have done his homework, so he didn't come.

Such type of communicative drills encourages students to connect form, meaning, and use because multiple correct responses are possible. In communicative drills, students respond to a prompt using the target grammar point (grammar point under consideration), but providing their own content. Moreover, this type of exercise is based on the real situation in the classroom which is similar to the life-like situation, with personalized meaningful responses. This gives a good chance of naturalistic language acquisition even within the instructed classroom teaching.

Well, now let's examine from the viewpoint of explicit and conscious grammatical knowledgr. Even from the viewpoint of getting conscious grammatical knowledge, the above mentioned textbook exercise does not give clear-cut concept of the difference between the meaning or use of 'may' and 'might'. It leaves up to the teachers to do this job, which only a few teachers can do successfully, and most of the teachers get the students confused. What's wrong in giving a brief but clear grammatical explanation in a sentence or two?

More recently, in a meta-analysis of experimental and quasi-experimental studies of instructed L2 acquisition published between 1980 and 1998 (Norris \& Ortega, 2000) reported robust evidence to suggest that explicit instruction (i.e. when learners' attention is clearly directed to the form of the language) is significantly more effective than implicit instruction (i.e. where no attention is paid to form).

Let's examine one more grammar exercise from Unit 3. The exercise goes like this:

Complete the sentence using either the past simple or past perfect tense.

\section{Example:}

She had already finished when the teacher said 'Stop!'

(a) The injured man (die) ........ before the doctor (examine) ....... him.

(b) I (phone) ........ to Sunita but she (go) ....... out to lunch.

(c) She (read) several of his books and (be) ....... interested to meet him.

(d) Suman (try) to learn some Japanese before she (visit) Tokyo.

(e) Prem (paint) the portrait after he (draw) a rough sketch.

(f) My friend (be) on a tour of India and (feel) exhausted. 
ISSN: 2362-1303 (Paper) | eISSN: 2362-1311(Online)

JOURNAL OF ADVANCED ACADEMIC RESEARCH (JAAR)

(g) He (pay) for the computer when he (save) up enough money.

Well, this exercise aims at giving practice on the use of two tenses: simple past and past perfect. What is wrong in giving the rules in one or two sentences so that the students are able to use these tenses with confidence.

In many situations explicit rule teaching is better for older students who are analytical learners.

Current theories of L2 learning suggest that the explicit knowledge of grammar is important in a number of respects. Such a knowledge of grammar allows learners to monitor their output, as well as trigger the essential process of noticing new structures in their language input (Schmidt 1990).

The purpose of teaching grammar (Ellis, 2002) is to assist learners to internalize the structures/rules of language, which can be used to generate an infinite number of similar sentences for communication, both written and spoken. For this purpose, clear rules must be stated to the students in grammar teaching process ( Ellis 2002).

From the viewpoint of exam preparation, absence of clear rules makes the students confused, and they cannot answer the questions with confidence. On the other hand, from the viewpoint of communicative competence, (i) more communicative oral task, and (ii) written task in discourse should be included in the textbook. So, instead of exercises in isolated sentences, they should be given in context: in the form of a short passage.

Although Section 5: Time for Grammar is followed by Section 6: Have your say, there is quasicommunicative type of exercise, not purely communicative task that demands free communication. It is better if this quasi-communicative practice is followed by free communicative practice, which can be monitored by the teacher by giving remedial lessons based on the errors found in free communicative task. Such type of lesson organization is lacking in class ten OEB.

Moreover, the reading passage is not connected with the target language structures of each unit. Hardly one or two sentences are found in the reading passage that are related to the target grammar point of that unit. The reading passage should be the breeding ground from where target language structures and grammar rule can be generated in a natural way. This is not the case with the reading comprehension passages found in class ten OEB.

The book contains patchy presentation of grammar points that may touch all the eleven chapters of the SLC grammar syllabus, but the practice exercises are not systematic and sufficient enough from the viewpoint of SLC exam preparation. Neither are they truly communication-oriented practice exercises, so they are not perfect from any viewpoint. 
ISSN: 2362-1303 (Paper) | eISSN: 2362-1311(Online)

JOURNAL OF ADVANCED ACADEMIC RESEARCH (JAAR)

The criterion of communicative functional skill building materials

Let's examine the class ten OEB from the viewpoint of functional competence materials. Section 6: Have your say seems to be for functional practice, for example, in Unit 2 "Have your say" deals with "agreeing and disagreeing" functions. However, the writer seems to be confused in many chapters. For example, in unit 1 grammar section aims at teaching the use of modals: may/might, and in the same unit, Speaking Section "Have your say" deals with degrees of probability using may/might. "Degrees of possibility" and the use of "may/might" are almost the same thing. Why not include some another function in "Have your say" section which is meant for presenting and practising functional materials.

It might be a good idea to reinforce the grammar points taught in a controlled way in the grammar section labelled as Time for grammar by engaging students to perform communicative tasks in "Have your say" section, but this is not the case in many units, for example, in Unit 2, we can find just guided communicative practice in "Have your say" section. So it is not clear whether "Have your say" section is for grammar reinforcement practice or for speaking skill development with functional competence.

Moreover, if you include grammar for consolidation purpose sacrificing functional practice in "Have your say" section, how to cover a large range of communicative functions? So, it would have been better if Grammar section had two sub-sections: (i) form-focussed grammar practice in isolated sentences, and (ii) communication-oriented grammar practice in discourse. In Speaking Section, i.e. in "Have your say" section, then, only communicative functions could be exclusively presented and practiced covering more functions with a view to developing speaking skill development.

The criterion of phonological practice materials

We all know that English language has four components: vocabulary, grammar, function and phonology, so the knowledge of English language is imperfect without phonological knowledge and skill. Sadly, the textbook gives zero exposure of phonological materials to students. Although as mentioned in the curriculum, one of the objectives of English teaching/learning is that the students should be able to speak with correct pronunciation, stress and intonation, the textbook writer has not given a damn about it. It's amazing why this important component is totally missing in the textbook, and why the textbook writers have not followed the guidelines of the curriculum. Naturally, the English pronunciation of general students is deplorable.

The criterion of macro skill building materials

Listening Skill Development: Of the four skills, if we start with listening skill, there are two sections related to listening skill: Section 8: Listen and match + Section 9. Listen and answer. Vol. 2. No. II 
ISSN: 2362-1303 (Paper) | eISSN: 2362-1311(Online)

JOURNAL OF ADVANCED ACADEMIC RESEARCH (JAAR)

July 2015

This is an easy job on the part of textbook writers to include such sections which aim at testing without teaching. These are skill testing exercises which are ridiculous without any skill building exercises. Why didn't the textbook writer include micro-skill building exercises that will ultimately lead to macro listening skill.

On the other hand, the quality of JEMC produced cassettes which are the sole sources on which listening skill tests are administered is also questionable on certain criteria. First of all, we should know that listening and listening practice are two different things. Any listening, for example, listening to Nepali speakers who are used to speaking every word distinctly has no value for listening practice because it doesn't contribute to listening skill building. There is no need of such listening because all Nepali learners of English may have listened to such English speaking for 20 or 30 years or even more. Despite this type of listening to English for a pretty long period, they are not able to understand English when they happen to listen to two native speakers speaking with each other.

Speaking Skill Development: In the book there are certainly some materials for speaking skill development, however, they are not sufficient on two grounds. Firstly, there is little coverage of communicative functions, so more functions and notions should be added. Secondly, there should be more variety in the types of speaking activities. Besides pair work, group work and role play, information gap activities should also be included. Most importantly, free oral communicative practice exercises is lacking in the class ten OEG. That must be included to develop genuine communicative ability among students. Besides, it's better if some attention is given to micro speaking skill activities and exercises which are desperately lacking in the book. They should be taken into consideration because these are the components that ultimately lead to macro speaking skill development.

Reading Skill Development: The reading passages are all right for reading comprehension skill building purpose, however, it would have better if there were clear instructions to the teacher how to teach a reading passage with one model at the appendix.

Writing Skill Development: Writing skill can be roughly divided into manipulative writing and free writing. The textbook contains just free writing exercises, and no manipulative writing exercises. There is no manipulative practice of each grammar point presented and practiced orally or in isolated sentences. There should have been focused practice of grammar points in context. Moreover, there is no practice of maintaining coherence and cohesion in a well structured paragraph. All these things should have been taken into consideration.

\section{CONCLUSION}

Class ten Our English Book has been written in line with communicative methodology, and it is a better book than its predecessors, however, it needs to be revised and rewritten to make it more learning outcome-oriented. 
ISSN: 2362-1303 (Paper) | eISSN: 2362-1311(Online)

JOURNAL OF ADVANCED ACADEMIC RESEARCH (JAAR) July 2015

A defective language learning is often attributed to defective syllabus design and defective course contents plus wrong way of teaching.

So far as course contents and organization is concerned, it is necessary to integrate semantic, formal and lexical syllabuses with varied language systems and components.

Course contents should be such that learners will be able to operate on key functions (for example: requesting asking for permission, etc), talk on basic notions (for example: time, speed, size, etc), communicate appropriately in specific situations (for example: at a shop, Dashian celebration, etc), discuss topics of interest (for example: load shedding, rural development, etc), communicate with high priority structures and impressive vocabulary, be proficient in the use of all macro skills: listening understanding, speaking, reading understanding and writing, and speak with phonological correctness.

\section{REFERENCES}

Ellis. R (2002).Grammar teaching-practice or consciousness-raising? In J. Richards \& W. Renandya (Eds.), Methodology in language teaching: An anthology ofcurrent practice (pp. 167-174). Cambridge: Cambridge University Press.

Norris, J. M., \& Ortega, L. (2000). Effectiveness of L2 instruction: a research synthesis and quantitative meta-analysis. Language Learning, 50(3), 417-528.

Schmidt, R. (1990). The Role of Consciousness in Second Language Learning.Applied Linguistics, 11, 129-158 .

Swan, M. (1985). A critical look at the communicative approach1 (ELTJournal 39/1 pp. 2-12.

Swan, M. (1985). A critical look at the communicative approach2 (ELTJournal 39/2 pp 77-87. 